\title{
Peningkatan Keterampilan Menyajikan Data Dalam Bentuk Tabel dan Diagram Batang Melalui Model Pembelajaran Kooperatif Tipe STAD
}

\author{
Anggie Tri Januantika \\ SD Negeri 1 Demangan \\ trijanuantika@gmail.com

\section{Article History} \\ received 3/12/2020
}

\begin{abstract}
This study aims to improve mathematics learning outcomes for grade IV students of SD Negeri 1 Demangan for the 2018/2019 academic year through STAD type cooperative learning. This research is a Classroom Action Research which was carried out in two cycles of improvement. Each cycle includes 4 stages, namely: planning, implementing actions, observing and reflecting. The success indicator of this research is if more than $85 \%$ of the fourth grade students of Elementary School 1 Demangan, Karangdowo, Klaten get a score of $>65$ or complete the KKM. In the study, it was found that student learning outcomes in the pre-cycle were the average value of 59,25 and the percentage of completeness was $41,67 \%$, the first cycle was the average value of 67,25 and the percentage of completeness was $75 \%$, while in the second cycle the average value was obtained. the average is 75,9 and the percentage of completeness is $91,67 \%$.
\end{abstract}

Keywords: elementary school, STAD, cooperative learning

\begin{abstract}
Abstrak
Penelitian ini bertujuan untuk meningkatkan hasil belajar matematika siswa kelas IV SD Negeri 1 Demangan tahun pelajaran 2018/2019 melalui pembelajaran kooperatif tipe STAD. Penelitian ini merupakan Penelitian Tindakan Kelas yang dilaksanakan dalam dua siklus perbaikan. Setiap siklus meliputi 4 tahap, yaitu: perencanaan, pelaksanaan tindakan, observasi dan refleksi. Indikator keberhasilan penelitian ini adalah jika lebih dari $85 \%$ siswa kelas IV SDN 1 Demangan, Karangdowo, Klaten memperoleh nilai $>65$ atau menyelesaikan KKM. Dalam penelitian ini diketahui bahwa hasil belajar siswa pada pra siklus nilai rata-rata 59,25 dan persentase ketuntasan 41,67\%, siklus I nilai rata-rata 67,25 dan persentase ketuntasan. ketuntasan $75 \%$, sedangkan pada siklus II diperoleh nilai rata-rata. rata-rata 75,9 dan persentase ketuntasan $91,67 \%$.
\end{abstract}

Kata kunci: sekolah dasar, STAD, pembelajaran kooperatif

Social, Humanities, and Education Studies (SHEs): Conference Series https://jurnal.uns.ac.id/shes

p-ISSN 2620-9284

e-ISSN 2620-9292 


\section{PENDAHULUAN}

Pendidikan di Indonesia mempunyai tujuan yang sangat baik, seperti yang tertulis di Undang-undang No. 20 tahun 2003 tentang tujuan Sistem Pendidikan Nasional Pasal 3, tujuan "Pendidikan nasional adalah mengembangkan potensi peserta didik agar menjadi manusia yang beriman dan bertakwa kepada Tuhan Yang Maha Esa, berakhlak mulia, sehat, berilmu, cakap, kreatif, mandiri, dan menjadi warga negara yang demokratis serta bertanggung jawab."

Pendidikan sebagai wadah atau disebut juga sebagai lembaga yang menampung, dimana dalam sebuah lembaga tersebut memiliki sebuah rancangan yang terarah dan terencana. Tetapi semua itu tidak akan terlaksana tanpa adanya implementasi dari pembelajaran.

Pembelajaran adalah proses interaksi peserta didik dan sumber belajar pada suatu lingkungan belajar, ini menurut Undang-undang No. 20 Tahun 2003 (Sri Anitah W, dkk 2014 : 115). Sedangkan menurut W.S Winkel (1983), belajar adalah suatu aktifitas mental atau psikis yang berlangsung dalam interaksi aktif dengan lingkungannya, yang menghasilkan perubahan-perubahan dalam pengetahuan atau pemahaman, ketrampilan dan nilai sikap perubahan itu bersifat relatif dan berbekas. Sujana (2005 : 3) hasil belajar adalah perubahan tingkah laku yang mencakup bidang kognitif, afektif dan psikomotorik.

Menurut Surya (Surya : 2017), matematika adalah mata pelajaran yang diajarkan dari jenjang pendidikan dasar sampai pendidikan menengah. Menurut Utari Sumarno (Nasution, 2017), pentingnya pemilikan kemampuan pemecahan masalah matematik pada siswa adalah bahwa kemampuan pemecahan masalah merupakan tujuan pengajaran matematika, bahkan sebagai jantungnya matematika

Sekarang ini peneliti melakukan observasi di SD Negeri 1 Demangan kelas IV kebanyakan siswanya pun beranggapan sama, bahwa Matematika adalah mata pelajaran sulit dan sukar dipahami. Hal ini dapat diketahui dari hasil wawancara dengan beberapa siswa kelas IV. Rekan guru Matematika yang lain pun ternyata punya keluhan sama pada saat menyampaikan pelajaran Matematika.

Peneliti memilih model pembelajaran STAD karena dengan metode ini siswa lebih aktif dalam pembelajaran. STAD merupakan salah satu metode pembelajaran kooperatif yang paling sederhana, dan merupakan model yang paling baik untuk permulaan bagi para guru yang baru menggunakan pendekatan kooperatif (dalam Slavin $2005:$ 143).

Menurut Isjoni dalam Tukiran Tuniredja (2012) tipe STAD yang dikembangkan oleh Slavin ini merupakan salah satu tipe kooperatif yang menekankan pada adanya aktifitas dan interaksi diantara siswa untuk saling memotivasi dan saling membantu dalam menguasai materi pelajaran guna mencapai hasil belajar maksimal.

Menurut Slavin langkah-langkah yang harus ditempuh dalam pembelajaran STAD adalah : 1) Sajian materi oleh guru. 2) Siswa bergabung dalam kelompok yang terdiri dari 4-6 orang. Sebaiknya kelompok dibagi secara heterogen yang terdiri atas siswa dengan beragam latar belakang, misalnya dari segi: prestasi, jenis kelamin, agama dan lain-lain. 3) Guru memberikan tugas kepada kelompok untuk mengerjakan latihan membahas suatu topik lanjutan bersamasama. Disini anggota kelompok harus bekerja sama. 4) Tes / kuis atau silang tanya antar kelompok. Skor kuis / tes tersebut untuk menentukan skor individu juga digunakan untuk menentukan skor kelompok. 5) Penguatan dari guru

Adapun langkah-langkah pembelajaran kooperatif tipe STAD menurut Rusman (2011 : 212-213) adalah: penyampaian tujuan dan motivasi, pembagian kelompok, presentasi dari guru, kegiatan belajar dalam tim (kerja tim), kuis (evaluasi), penghargaan prestasi tim.

Keberhasilan model pembelajaran kooperatif tipe STAD ditunjang dengan beberapa hasil penelitian terdahulu. Hasil penelitian Masdalilah peningkatan hasil 
belajar matematika, penelitian Yolanda dan Fikri penerapan model kooperatif tipe STAD untuk meningkatkan aktifitas siswa, dan penelitian Atrika pengaruh penggunaan model kooperatif tipe STAD terhadap prestasi belajar dan keaktifan siswa.

\section{METODE}

Pelaksanaan penelitian tindakan kelas ini mengikuti tahap tindakan yang bersiklus. Model penelitian ini mengacu pada modifikasi spiral yang dicantumkan Kemmis dan Mc. Taggart (dalam Dahlia : 2012) tiap siklus dilakukan beberapa tahap, yaitu 1) Perencanaan tindakan, 2) Pelaksanaan tindakan, 3) Observasi, dan 4) Refleksi.

PTK (Penelitian Tindakan Kelas) ini menggunakan dua siklus. Pelaksanaan siklus dilakukan dengan dua pertemuan. Subjek penelitian ini adalah guru dan 12 peserta didik di kelas IV SD Negeri 1 Demangan, Karangdowo, Klaten Tahun Ajaran 2018/2019. Teknik pengumpulan data dengan teknik tes. Data berupa hasil belajar. Sedangkan teknik pengumpulan data dengan teknik non tes dilakukan dengan teknik observasi dan dokumentasi. Data berupa aktivitas belajar. Teknik analisis data dengan teknik deskriptif, yaitu deskriptif kualitatif dan deskriptif komparatif. Analisis data kualitatif dengan deskriptif kualitatif sesuai dengan hasil observasi dan dokumentasi. Sedangkan analisis data kuantitatif dengan deskriptif komparatif sesuai dengan hasil tes.

Indikator kinerja dalam penelitian tindakan kelas ini memiliki target $85 \%$ dari siswa memiliki hasil lebih baik dari KKM (65).

\section{HASIL DAN PEMBAHASAN}

Hasil kegiatan tes, observasi dan wawancara pada kondisi awal dapat disimpulkan bahwa kemampuan siswa dalam menyelesaikan soal penyajian data dalam bentuk tabel dan diagram batang masih rendah. Hasil prasiklus dapat dilihat melalui Tabel 1 sebagai berikut:

Tabel 1. Distribusi Frekuensi Data Nilai Kemampuan Peserta Didik Menyelesaikan Soal Prasiklus

\begin{tabular}{ccc}
\hline Interval Nilai & Frekuensi & Presentase \\
\hline $30-39$ & 1 & $8,33 \%$ \\
$40-49$ & 1 & $8,33 \%$ \\
$50-59$ & 3 & $25 \%$ \\
$60-69$ & 4 & $33,33 \%$ \\
$70-79$ & 3 & $25 \%$ \\
$80-89$ & 0 & $0 \%$ \\
Jumlah & $\mathbf{1 2}$ & $\mathbf{1 0 0 \%}$ \\
Nilai Rata-rata & & $\mathbf{5 9 , 2 5}$ \\
Ketuntasan Klasikal & $\mathbf{4 1 , 6 7 \%}$ \\
Presentase Nilai di bawah KKM & $\mathbf{5 8 , 3 3 \%}$ \\
\hline
\end{tabular}

Tabel 1 menunjukkan dari 12 siswa persentase ketuntasan klasikal hanya $41,67 \%$ atau 5 siswa yang mampu mencapai nikai KKM (65) dan 58,33\% siswa atau 7 siswa belum mampu mencapai nilai KKM (65). Nilai rata-rata kelas mencapai 59,25. Hal tersebut menunjukkan bahwa kemampuan siswa dalam menyelesaikan soal penyajian data dalam bentuk tabel dan diagram batang masih rendah. Upaya untuk meningkatkan kemampuan siswa dilakukan oleh peneliti dengan berkolaborasi dengan guru dalam menyusun materi dan perencanaan tindakan dengan model pembelajaran kooperatif tipe STAD (Student Teams Achievement Division) sebagai solusi dalam mengatasi rendahnya kemampuan siswa dalam menyelesaikan soal penyajian data dalam bentuk tabel dan diagram batang. Tindakan yang dilakukan pada siklus I 
dengan menerapkan model pembelajaran kooperatif tipe STAD (Student Teams Achievement Division). Hasil dari siklus I dapat dilihat dari Tabel 2 sebagai berikut:

Tabel 2. Distribusi Frekuensi Data Nilai Kemampuan Peserta Didik Menyelesaikan Soal Siklus I

\begin{tabular}{ccc}
\hline Interval Nilai & Frekuensi & Presentase \\
\hline $30-39$ & 0 & $0 \%$ \\
$40-49$ & 1 & $8,33 \%$ \\
$50-59$ & 1 & $8,33 \%$ \\
$60-69$ & 5 & $41,67 \%$ \\
$70-79$ & 4 & $33,33 \%$ \\
$80-89$ & 1 & $8,33 \%$ \\
Jumlah & $\mathbf{1 2}$ & $\mathbf{1 0 0 \%}$ \\
Nilai Rata-rata & & $\mathbf{6 7 , 2 5}$ \\
Ketuntasan Klasikal & $\mathbf{7 5 \%}$ \\
Presentase Nilai di bawah KKM & $\mathbf{2 5 \%}$ \\
\hline
\end{tabular}

Tabel 2 menunjukkan dari 12 siswa persentase ketuntasan klasikal kemampuan menyelesaikan soal penyajian data dalam bentuk tabel dan diagram batang siswa mengalami peningkatan dari prasiklus, akan tetapi belum mencapai indikator kerja yaitu $85 \%$. Pada prasiklus peningkatan ketuntasan klasikal dari $41,67 \%$ menjadi $75 \%$. Rata- rata pada siklus I dari 59,25 menjadi 67,25. Pada siklus I, pembelajaran sudah berlangsung cukup efektif ditandai dengan meningkatnya kemampuan siswa dalam menyelesaikan soal penyajian data dalam bentuk tabel dan diagram batang. Oleh karena itu dilakukan perbaikan pada pembelajaran dengan tindakan ke siklus II. Pembelajaran pada siklus II merupakan refleksi dari pelaksanaan pembelajaran siklus I. Hasil belajar yang dicapai pada siklus II dapat dilihat pada Tabel 3 sebagai berikut:

Tabel 3. Distribusi Frekuensi Data Nilai Kemampuan Peserta Didik Menyelesaikan Soal Siklus II

\begin{tabular}{ccc}
\hline Interval Nilai & Frekuensi & Presentase \\
\hline $30-39$ & 0 & $0 \%$ \\
$40-49$ & 0 & $0 \%$ \\
$50-59$ & 0 & $0 \%$ \\
$60-69$ & 3 & $25 \%$ \\
$70-79$ & 4 & $33,33 \%$ \\
$80-89$ & 5 & $41,67 \%$ \\
Jumlah & $\mathbf{1 2}$ & $\mathbf{1 0 0 \%}$ \\
Nilai Rata-rata & & $\mathbf{7 5 , 9 2}$ \\
Ketuntasan Klasikal & $\mathbf{9 1 , 6 7 \%}$ \\
Presentase Nilai di bawah KKM & $\mathbf{8 , 3 3 \%}$ \\
\hline
\end{tabular}

Tabel 3 menunjukkan bahwa persentase ketuntasan klasikal kemampuan menyelesaikan soal penyajian data dalam bentuk tabel dan diagram batang siswa mengalami peningkatan dari siklus I ke siklus II dan sudah mencapai indikator kerja yaitu $85 \%$. Pada siklus I peningkatan ketuntasan klasikal dari 75\% menjadi $91,67 \%$. Rata-rata meningkat dari siklus I dari 67,25 menjadi 75,92. Perbandingan nilai kemampuan menyelesaikan soal penyajian data dalam bentuk tabel dan diagram batang antar siklus dapat dilihat pada Tabel 4 di bawah ini: 
Tabel 4. Perbandingan Nilai Kemampuan Peserta Didik Menyelesaikan Soal Antar

\begin{tabular}{lccc}
\multicolumn{4}{c}{ Siklus } \\
\hline Keterangan & Prasiklus & Siklus I & Siklus II \\
\hline Nilai Rata-rata Klasikal & 59,25 & 67,25 & 75,92 \\
Nilai Tertinggi & 75 & 80 & 83 \\
Nilai Terendah & 35 & 45 & 63 \\
Presentase Ketuntasan Klasikal & $41,67 \%$ & $75 \%$ & $91,67 \%$ \\
\hline
\end{tabular}

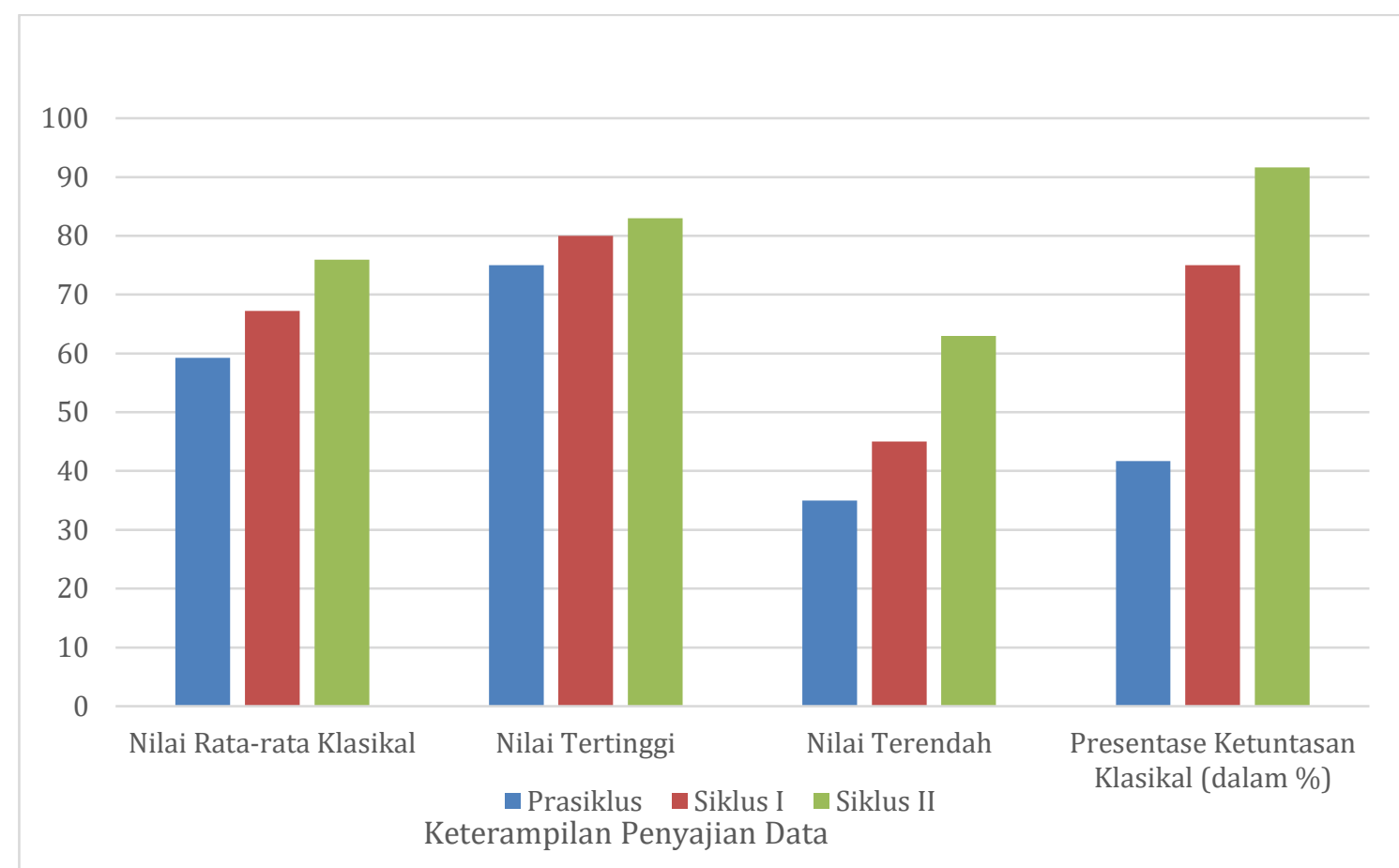

\section{Gambar 1. Hasil Observasi Keterampilan Penyajian Data Dalam Bentuk Tabel dan Diagram Batang}

Berdasarkan tabel di atas dapat diketahui bahwa prasiklus, siklus I, dan siklus II mengalami peningkatan. Hal tersebut dapat dilihat dari nilai rata-rata klasikal, nilai tertinggi, nilai terendah, dan presentase ketuntasan klasikal.

Hasil penelitian ini sejalan dengan penelitian yang dilakukan Masdalilah yang menyatakan bahwa hasil penelitian menunjukkan nilai rata-rata kelas yang diperoleh siswa sebelum tindakan adalah 54,8 dengan persentase 9,5\% atau 19 siswa yang tuntas dari 21 siswa, pada siklus I menjadi 62,56\% dengan rata-rata 64,3 dan pada siklus II diperoleh $85,2 \%$ siswa tuntas dengan rata-rata 76,7 . Sedangkan penelitian yang dilakukan Fikri dikatakan bahwa rata-rata hasil belajar siswa dengan menggunakan model pembelajaran STAD nilai rata-rata nilai pretest 58,17 menjadi 81,33 pada post-test sehingga nampak selisih 23,16 . Maka dapat disimpulkan bahwa model pembelajaran STAD dalam materi bangun ruang dapat meningkatkan hasil belajar siswa kelas V SDN 01 Doplang dan Atrika menyatakan kelompok eksperimen diperoleh nilai rata-rata pretest sebesar 67,6 dan nilai posttest sebesar 91,8 . Pada kelompok kontrol diperoleh nilai rata-rata pretest 64,8 dan nilai posttest sebesar 80,0 . Keaktifan siswa pada kelas eksperimen sebeleum diberikan metode STAD (Student Team Achievment Division) sebesar $20 \%$ dari hasil tersebut dapat disimpulkan bahwa penggunaan metode STAD (Student Team Achievment Division) memberikan pengaruh positif terhadap keaktifan dan prestasi belajar siswa kela IV SD N Secang 2. 
Sejalan dengan itu Yolanda yang menyatakan bahwa penerapan model pembelajaran kooperatif tipe STAD membawa dampak yang positif terhadap peningkatan aktivitas siswa, khususnya pada materi pengumpulan data dengan teknikpencatatan langsung dan penyajian data ke dalam bentuk diagram batang, maka diharapkan guru dapat menggunakannya.

\section{SIMPULAN}

Hasil Penelitian Tindakan Kelas (PTK) berkesimpulan bahwa kemampuan pemahaman konsep penyajian data dalam bentuk tabel dan diagram batang dengan penerapan tipe Student Teams Achievement Division (STAD) pada siswa di kelas IV SD Negeri 1 Demangan, Karangdowo, Klaten tahun ajaran 2018/2019 terbukti meningkat. Kontribusi positif tersebut adalah adanya peningkatan persentase ketuntasan dari tahapan pra siklus, siklus I hingga siklus II. Dari persentase ketuntasan pra siklus $41,67 \%$ meningkat menjadi $75 \%$ pada siklus I selanjutnya meningkat menjadi $91,67 \%$ di siklus II. Implikasi teoritis pada penelitian ini yakni dapat menambah wawasan keilmuan dan sebagai referensi bagi penelitian sejenis yang akan datang. Selain itu, implikasi praktis dari hasil penelitian ini bagi kegiatan pembelajaran matematika, yaitu dengan peningkatan keterampilan menyajikan data dalam bentuktabel dan diagram batang melalui model pembelajaran kooperatif tipe Student Teams Achievement Division (STAD).

\section{DAFTAR PUSTAKA}

Dahlia. 2012. Penelitian Tindakan Kelas. Palu: Edukasi Mitra Grafika.

Masdalilah. 2016. Meningkatkan Hasil Belajar Matematika dengan Model STAD di Kelas VI SD Negeri No. 028 Lumban Dolok. Jurnal Pendidikan: Vol 6 (1) hlm 126-138.

Nasution,Z.M., Surya,Edy, dan Manullang,M. (2017). Perbedaan Kemampuan Pemecahan Masalah Matematik Dan Motivasi Belajar Siswa Yang Diberi Pendekatan Pembelajaran Berbasis Masalah Dengan Pendidikan Matematika. Jurnal Matematika: Vol. 10, No. 1 (67-78).

Nur Samsu, Fikri, Intan Rahmawati, Suyitno. 2019. Keefektifan Model Pembelajaran STAD terhadap Hasil Belajar Matematika Materi Bangun Ruang. Jurnal PGSD Vol. 3, No. 3, 2019, pp 344-350.

Prita Nurvitasari, Atrika. 2019. Pengaruh Penggunaan Model Pembelajaran Kooperatif Tipe STAD (Student Teams Achievment Division) Terhadap Prestasi Belajar dan Keaktifan Siswa Pada Materi Pelajaran Matematika. Skripsi.

Rusman. 2011. Model-Model Pembelajaran Mengembangkan Profesionalisme Guru. Jakarta: PT. Raja Grafindo Persada

Slavin, Robert E. 2005. Cooperative Learning Teori, Riset dan Praktik. Bandung: Nusa Media

Sudjana, N. 2010. Penilaian Hasil Proses Belajar Mengajar. Bandung: PT Remaja Rosdakarya

Surya, E., Sari, N. 2017. Analysis Effectiveness of using Problem Posing Model in Mathematical Learning. Basic and Applied Research (IJSBAR). Vol. 33, No 3 (1321).

Taniredja, Tukiran dkk. 2012. Model-model Pembelajaran Inovatif. Bandung: Alfabeta.

Tirta Sari, Yolanda \& Osa Juarsa. 2017. Penerapan Model Cooperative Learning Tipe Student Team Achievment Division untuk Meningkatkan Aktivitas Siswa Pada Pembelajaran Matematika. Jurnal Pendidikan: Vol 16 No.2. 
W, Sri Anitah, dkk. 2014. Strategi Pembelajaran di SD. Tangerang Selatan: Universitas terbuka

Winkel, WS. 1983. Psikologi Pengajaran. Jakarta: PT. Gramedia. 